\title{
An Analysis of the Performance of Automobile Industry in India
}

\author{
Arvinder Kaur \\ Independent Consultant, Doctorate in Economics, PSE, G.N.D.U., Amritsar, New Delhi, India. Email: arvinderkaurkalsi@ gmail.com \\ DOI: 10.38177/ajast.2020.4211
}

The paper has examined the performance of Automobile Industry in India. The paper has used secondary data for the production, exports and imports of Automobile sector for the period 2001 to 2018. The performance of automobiles has been measured by calculating compound annual growth rate, Y-O-Y growth rate of production, export share in total exports, trade balance, compound annual growth rate of exports, market share in world and revealed comparative advantage of automobile industry. The two-wheeler segment accounted for a large part of the total production of automobiles in the country and increased significantly during 2011-2018. Production of commercial vehicles also increased considerably. The domestic sale of two-wheelers gradually increased, but sales of all other vehicles increased with some variations. India has a trade surplus in total automobiles. India experienced trade deficit only in the categories 'Motor vehicles parts and accessories', and 'Trailers'. The compound annual growth rate (CAGR) of total road vehicles as well as of all the vehicles decreased significantly during 2011-2018. Revealed comparative index showed that India does no have a comparative advantage in automotive exports. It showed comparative advantage only in the product category 'Cycles, etc., Motorised or not'. Research and development activities in the production sector should be carried out in order to improve the quality of automobiles and to make them competitive in the world market. Good infrastructure facilities should be provided in the country. Government should organize training programme for the workers.

Keywords: Automobiles, Production, Exports, CAGR, RCA.

\section{Introduction}

The automotive industry is regarded as one of the key sectors in India. The automotive sector has a prominent position in the Indian economy due to its powerful forward and backward links with several main sections of the economy. It accounts for more than 7.1 per cent of India's GDP and accounts for almost 22 per cent of India's manufacturing GDP. (Source: PIB).

India was found to be fourth largest manufacturer of cars and seventh largest manufacturer of commercial vehicles in 2019. Automobiles lead the capital goods sector. It comprises passenger vehicles, commercial vehicles, three wheelers, two wheelers and quadricycles.

India's economic reforms were initiated in mid-1991 with a primary focus on trade policy reforms. Government of India has taken several measures to robust the industrial growth of the economy.

The trade policy changes of India since 1991 aimed at creating a far more open and competitive environment.

Since 1991, the Government eliminated quotas, along with sharp tariff cuts, which resulted in significantly opening up of the economy to global competition.

The objective of the paper is to examine the performance of automobile sector in India and to suggest the policy measures to improve it. To study the performance of automobiles, data for production and sales of automobiles has been taken from SIAM and data for the exports and imports has been taken from uncomtrade.

\section{Production of Automobiles}

Table 1 shows the trends in Automobiles production during the period 2013-14 to 2018-19. The production of automobile grew at CAGR of 7 percent with increase in total production to 30 million vehicles in 2018-19. 
Table 1: Automobile Production Trends (in numbers)

\begin{tabular}{|l|c|c|c|c|c|c|c|c|}
\hline \multicolumn{1}{|c|}{ Category } & $\mathbf{2 0 1 2 - 1 3}$ & $\mathbf{2 0 1 3 - 1 4}$ & $\mathbf{2 0 1 4 - 1 5}$ & $\mathbf{2 0 1 5 - 1 6}$ & $\mathbf{2 0 1 6 - 1 7}$ & $\mathbf{2 0 1 7 - 1 8}$ & $\mathbf{2 0 1 8 - 1 9}$ & CAGR \\
\hline $\begin{array}{l}\text { Passenger } \\
\text { Vehicles }\end{array}$ & $3,231,058$ & $3,087,973$ & $3,221,419$ & $3,465,045$ & $3,801,670$ & $4,020,267$ & $4,026,047$ & $3.7 \%$ \\
\hline $\begin{array}{l}\text { Commercial } \\
\text { Vehicles }\end{array}$ & 832,649 & 699,035 & 698,298 & 786,692 & 810,253 & 895,448 & $1,112,176$ & $4.9 \%$ \\
\hline $\begin{array}{l}\text { Three } \\
\text { Wheelers }\end{array}$ & 839,748 & 830,108 & 949,019 & 934,104 & 783,721 & $1,022,181$ & $1,268,723$ & $7.1 \%$ \\
\hline $\begin{array}{l}\text { Two Wheelers } \\
\text { Quadri-cycle }\end{array}$ & $15,744,156$ & $16,883,049$ & $18,489,311$ & $18,830,227$ & $19,933,739$ & $23,154,838$ & $24,503,086$ & $7.7 \%$ \\
\hline Grand Total & $\mathbf{2 0 , 6 4 7 , 6 1 1}$ & $\mathbf{2 1 , 5 0 0 , 1 6 5}$ & $\mathbf{2 3 , 3 5 8 , 0 4 7}$ & $\mathbf{2 4 , 0 1 6 , 5 9 9}$ & $\mathbf{2 5 , 3 3 0 , 9 6 7}$ & $\mathbf{2 9 , 0 9 4 , 4 4 7}$ & $\mathbf{3 0 , 9 1 5 , 4 2 0}$ & $7.0 \%$ \\
\hline
\end{tabular}

Source: http://www.siamindia.com/

The production of two wheelers increased significantly to 24.5 million in 2018-19 at a CAGR of 7.7 percent. The production of commercial vehicles increased to 1.11 million in 2018-19 at the compound annual growth rate of 4.9 percent rate during the period. In 2018, India was the 7th largest manufacturer of commercial vehicles. The compound annual growth rate of all the vehicles was positive indicating rise in production of the vehicles over the period2012-13 to 2018-19.

\section{Y-O-Y growth rate of the production of Automobiles}

Table 2 shows year over year growth rate of the production of automobiles during the period 2012-13 to 2018-19.

Table 2: Production of Automobiles (Y-O-Y) growth rate (\% change)

\begin{tabular}{|l|c|c|c|c|c|c|c|}
\hline Category & $\mathbf{2 0 1 2 - 1 3}$ & $\mathbf{2 0 1 3 - 1 4}$ & $\mathbf{2 0 1 4 - 1 5}$ & $\mathbf{2 0 1 5 - 1 6}$ & $\mathbf{2 0 1 6 - 1 7}$ & $\mathbf{2 0 1 7 - 1 8}$ & $\mathbf{2 0 1 8 - 1 9}$ \\
\hline Passenger Vehicles & 2.63 & -4.43 & 4.32 & 7.56 & 9.71 & 5.75 & 0.14 \\
\hline Commercial & -11.59 & -16.05 & -0.11 & 12.66 & 2.99 & 10.51 & 24.20 \\
\hline Three Wheelers & -4.71 & -1.15 & 14.32 & -1.57 & -16.10 & 30.43 & 24.12 \\
\hline Two Wheelers & 2.01 & 7.23 & 9.51 & 1.84 & 5.86 & 16.16 & 5.82 \\
\hline Quadricycle* & & & & & 198.31 & 8.14 & 214.54 \\
\hline Grand Total & 1.29 & 4.13 & 8.64 & 2.82 & 5.47 & 14.86 & 6.26 \\
\hline
\end{tabular}

\section{Source: Author Calculations}

The production of commercial vehicles declined till 2014-15, it was due to sluggish market demand. But the production increased significantly at 24.2 percent rate in 2018-19. Though three-wheelers have witnessed a decline in production for couple of years but exhibited a significant growth in 2017-18. The production of all the vehicles declined in 2013-14 except two wheelers. This happened due to the slowdown in the global economy. Total production of automobiles declined in 2015-16 due to reduction in the production of two and three wheelers. The 
slowing economy is the main reason for the plight of automobile industry. Production of quadric-cycle increased significantly at 214.5 percent rate in 2018-19. While the total growth declined in 2012-13 and 2015-16, the industry experienced positive growth in other periods.

Graph 1: Automobile Production in India (2012-13 to 2018-19)

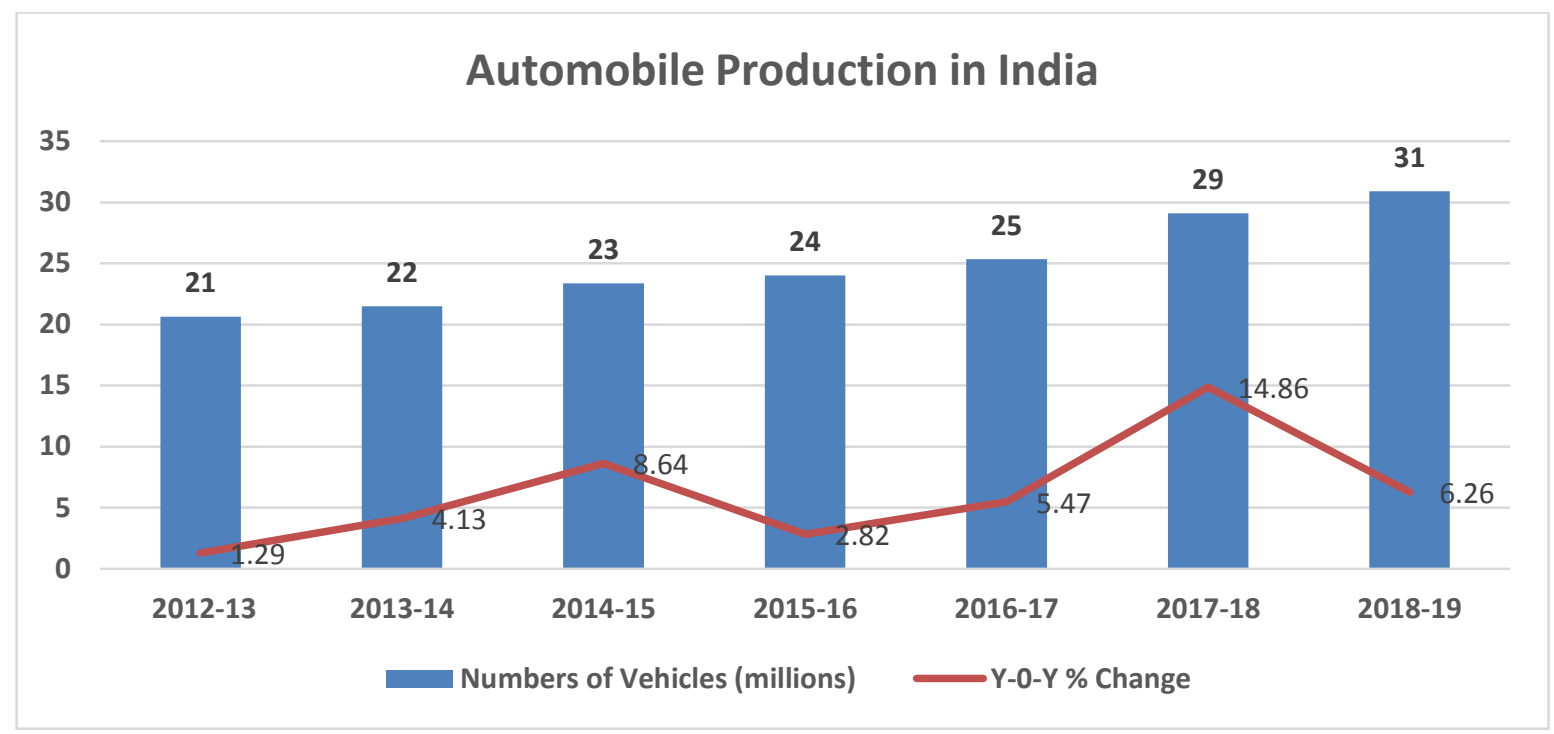

\section{Domestic Market share of Automobiles}

The segment of the two-wheelers constituted a major part of the total production of automobiles in the country, accounting for $80 \%$ of production in the year 2018-19, followed by the passenger vehicles segment (13\% share), Commercial Vehicles (4\% share) and three wheelers (3\% share).

Graph 2: Domestic market Share of Automobiles

\section{Domestic Market share for 2018-19}

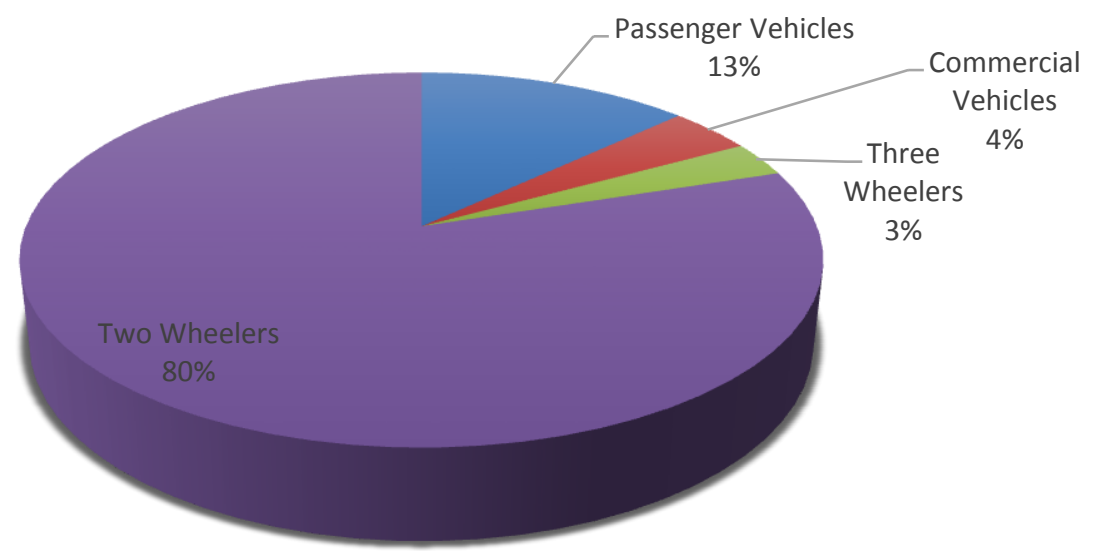

\section{Domestic Sale of Automobiles in India}

Table 3 shows the domestic sales of automobiles in India during the period 2011-12 to 2018-19. 
Table 3: Domestic Sales of Automobiles in India (No. of Units in million)

\begin{tabular}{|l|c|c|c|c|c|c|c|c|}
\hline Category & $\mathbf{2 0 1 1 - 1 2}$ & $\mathbf{2 0 1 2 - 1 3}$ & $\mathbf{2 0 1 3 - 1 4}$ & $\mathbf{2 0 1 4 - 1 5}$ & $\mathbf{2 0 1 5 - 1 6}$ & $\mathbf{2 0 1 6 - 1 7}$ & $\mathbf{2 0 1 7 - 1 8}$ & $\mathbf{2 0 1 8 - 1 9}$ \\
\hline $\begin{array}{l}\text { Passenger } \\
\text { Vehicles }\end{array}$ & 2.63 & 2.67 & 2.50 & 2.60 & 2.79 & 3.05 & 3.29 & 3.38 \\
\hline $\begin{array}{l}\text { Commercial } \\
\text { Vehicles }\end{array}$ & 0.81 & 0.79 & 0.63 & 0.61 & 0.69 & 0.71 & 0.86 & 1.01 \\
\hline Three Wheelers & 0.51 & 0.54 & 0.48 & 0.53 & 0.54 & 0.51 & 0.64 & 0.70 \\
\hline Two Wheelers & 13.41 & 13.80 & 14.81 & 15.98 & 16.46 & 17.59 & 20.20 & 21.18 \\
\hline Grand Total & 17.36 & 17.79 & 18.42 & 19.72 & 20.47 & 21.86 & 24.98 & 26.27 \\
\hline
\end{tabular}

Source: http://www.siamindia.com/

Domestic sales of total automobiles in India followed an increasing trend over the period 2011-12 to 2018-19.The rationale behind growing demand was rise in the income of middle class. While the domestic sales of both passenger vehicles and commercial vehicles declined in 2012-13 and 2013-14. The state of the economy caused decline in the demand of the overall segments of passenger vehicles (cars, utility vehicles and vans) and commercial vehicles. Two wheelers were at the top in terms of domestic sales, followed by passenger vehicles, commercial vehicles and three wheelers during the period. Domestic sale of two wheelers increased gradually, but sales of all other vehicles increased with some variations.

\section{Export Performance of Automobiles}

Export performance of the automobiles sector has been examined in terms of shares in total exports, export to import ratio, growth rates of exports, and share in world exports of capital goods.

\section{Export to Imports ratio and self-sufficiency of the Automobiles sector in India}

Capital goods sector plays an important role in the manufacturing of goods and services. Automobiles are the prominent part of the capital goods sector. Though India could not attain self-sufficiency in the capital goods sector, but automobiles have shown a different picture. The following table shows ratio of exports to imports of automobiles in India. If the export / import ratio is greater than one, the country will be independent and competitive. But, if the export / import ratio is below one, the country is dependent and less competitive. Table 4 shows exports and imports and trade balance of automobiles sector during the period 2000 to 2018.

Table 4: Exports to Imports Ratio of Automobiles sector (2000-2018)

\begin{tabular}{|c|l|c|c|c|c|c|}
\hline SITC & Product categories & $\mathbf{2 0 0 0}$ & $\mathbf{2 0 0 5}$ & $\mathbf{2 0 1 0}$ & $\mathbf{2 0 1 5}$ & $\mathbf{2 0 1 8}$ \\
\hline $\mathbf{7 8 1}$ & Passenger motor vehicles (excluding buses) & 6.15 & 7.29 & 9.81 & 24 & 22.97 \\
\hline $\mathbf{7 8 2}$ & Lorries \& special purposes motor vehicles & 8.82 & 5.6 & 6.82 & 13.07 & 11.74 \\
\hline $\mathbf{7 8 3}$ & Road motor vehicles & 112.97 & 265.81 & 88.8 & 30.61 & 28.97 \\
\hline
\end{tabular}




\begin{tabular}{|c|c|c|c|c|c|c|}
\hline $\mathbf{7 8 4}$ & Motor vehicle parts and accessories & 1.29 & 1.62 & 0.72 & 1.07 & 0.88 \\
\hline $\mathbf{7 8 5}$ & Cycles, scooters, motorized or not; invalid & 19.43 & 7.18 & 2.54 & 3.81 & 2.15 \\
\hline $\mathbf{7 8 6}$ & Trailers \& other vehicles, not motorized & 3.94 & 1.24 & 0.43 & 0.74 & 0.71 \\
\hline
\end{tabular}

Source: uncomtrade, based on author calculation

India was found to be self-sufficient in all the 6 categories of automobiles in 2000. Export-import ratio was highest for 'Road Motor Vehicles' followed by 'Cycles, scooters, motorized or not.', 'Tractors and motor' and 'Lorries and special purpose motor vehicles' in 2000.

In 2018, India was found to be self-sufficient only in 4 product categories of automobiles. Export-import ratio was highest in the 'Road motor vehicles' followed by 'Passenger motor vehicles', and 'Lorries and special purposes motor vehicles'. But India has lost sufficiency in the product categories of 'Motor vehicles parts and accessories' and 'Trailers and other vehicles, not motorized'.

India showed competitiveness in the product categories, 'Motor vehicles parts', and 'Trailers and other vehicles parts' in 2000, but lost it in 2018.

\section{Export share of Automobiles in Total Exports of India}

Table 5 shows the export share of automobiles in total exports of India. The share of automobile in total exports of India showed an improvement as the export share of 'Total Road Vehicles' has increased from 1.92 percent in 1990 to 5.55 percent in 2018. It indicates that demand of automobiles at global level has increased.

The 'Passenger motor vehicles' and 'Motor vehicles parts' and 'Cycles motorized or not' were in the list of top 10 capital products in total exports in 2018.

The performance of automobiles sector has been improving, as the share in total exports has been increasing since 1990.

Table 5: Export share of Automobiles in Total Exports of India (\% share)

\begin{tabular}{|c|c|c|c|c|c|}
\hline SITC code & Product categories & 1990 & 2000 & 2010 & 2018 \\
\hline $\mathbf{7 8}$ & Total Road Vehicles & 1.92 & 2.15 & 3.97 & 5.55 \\
\hline $\mathbf{7 8 1}$ & Passenger motor vehicles (excluding buses) & 0.13 & 0.24 & 2.05 & 2.23 \\
\hline $\mathbf{7 8 2}$ & Lorries special motor vehicles nes & 0.06 & 0.16 & 0.34 & 0.43 \\
\hline $\mathbf{7 8 3}$ & Road Motor Vehicles Nes & 0.21 & 0.16 & 0.14 & 0.08 \\
\hline $\mathbf{7 8 4}$ & Motor vehicles parts, Accessories nes & 0.67 & 0.85 & 0.95 & 1.89 \\
\hline $\mathbf{7 8 5}$ & Cycles, etc Motorized or not & 0.64 & 0.72 & 0.48 & 0.90 \\
\hline $\mathbf{7 8 6}$ & Trailers, Non-motor vehicles, nes & 0.21 & 0.02 & 0.01 & 0.03 \\
\hline
\end{tabular}


The export share of 'passenger motor vehicles ' and ' motor vehicle parts ' has steadily increased to around 2\% in 2018. The shares of 'Trailer, non-motor vehicles, nes' and 'Road motor vehicles nes' were very less since 1990 and could not improve over the period.

Though the share of 'Lorries special motor vehicles nes' was very less in 1990, but it has been improving gradually. There is a marginal improvement in the export shares of 'Cycles etc motorized or not' in 2018 compared to 1990.

\section{Compound annual growth rates of Automobiles Export}

Export performance of automobiles has been measured in terms of the compound annual growth rates of exports during the period 2001-2005, 2006-2010 and 2011-2018.

Table 6: Compound Annual Growth rates of the Exports of Automobiles

\begin{tabular}{|c|c|c|c|c|}
\hline SITC CODE & Product Categories & $2001-05$ & $2006-10$ & $2011-18$ \\
\hline 78 & Total Road Vehicles & $38.6 \%$ & $26.4 \%$ & $9.5 \%$ \\
\hline 781 & Passenger motor vehicles (excluding buses) & $80.6 \%$ & $44.0 \%$ & $10.2 \%$ \\
\hline 782 & Lorries and special purposes motor vehicles & $41.8 \%$ & $36.5 \%$ & $6.4 \%$ \\
\hline 783 & Road motor vehicles, nes & $56.3 \%$ & $11.5 \%$ & $0.6 \%$ \\
\hline 784 & Motor vehicle parts and accessories, nes & $36.6 \%$ & $11.0 \%$ & $10.5 \%$ \\
\hline 785 & Cycles, scooters, motorized or not; invalid & $12.4 \%$ & $17.3 \%$ & $8.2 \%$ \\
\hline 7851 & Motorcycles, auto-cycles; side-cars of all & $32.3 \%$ & $24.2 \%$ & $8.2 \%$ \\
\hline 7852 & Cycles, not motorized & $-0.4 \%$ & $3.1 \%$ & $-0.8 \%$ \\
\hline 786 & Trailers, and other vehicles, not motorized, & $22.0 \%$ & $5.7 \%$ & $9.6 \%$ \\
\hline
\end{tabular}

Source: Author calculations

Table 6 shows that the compound annual growth rate (CAGR) of 'Total Road vehicles' declined significantly from 38.6 percent during 2001-2005 to 9.5 percent during 2011-2018. This was due to decline in the growth rates of all vehicles over the same period.

The growth rate of the product categories 'Passenger motor vehicles (excluding buses)', 'Lorries and special purposes motor vehicles', 'Road motor vehicles, nes', 'Motor vehicle parts and accessories, nes' declined drastically over the period 2011-2018 compared to 2001-2005.

The product category 'Cycles, not motorized' experienced negative growth rate during the period 2001-2005 and 2011-2018.

The decline in exports has been on account of slowdown in the global economy in 2012-13.

\section{Export Performance of Automobiles in Terms of World' Export Shares}

Table 7 shows categories wise export share of automobiles in world. 
Table 7: Product-wise Share of Automobiles in World

\begin{tabular}{|c|c|c|c|c|c|c|c|}
\hline Code & Group Description & $\mathbf{1 9 9 5}$ & $\mathbf{2 0 0 0}$ & $\mathbf{2 0 0 5}$ & $\mathbf{2 0 1 0}$ & $\mathbf{2 0 1 5}$ & $\mathbf{2 0 1 7}$ \\
\hline 78 & Total Road Vehicles & 0.20 & 0.17 & 0.35 & 0.82 & 1.00 & 1.10 \\
\hline 781 & Passenger motor vehicles (excluding buses) & 0.08 & 0.03 & 0.19 & 0.81 & 0.79 & 0.88 \\
\hline 782 & Lorries special motor vehicles nes & 0.08 & 0.12 & 0.24 & 0.70 & 0.64 & 0.67 \\
\hline 783 & Road Motor Vehicles Nes & 0.33 & 0.42 & 0.63 & 0.95 & 0.60 & 0.68 \\
\hline 784 & Motor vehicles parts, Accessories nes & 0.25 & 0.25 & 0.54 & 0.69 & 1.17 & 1.32 \\
\hline 785 & Cycles, etc Motorized or not & 1.76 & 1.42 & 1.46 & 2.65 & 4.45 & 4.39 \\
\hline 786 & Trailers, non-motor vehicles, nes & 0.03 & 0.06 & 0.09 & 0.12 & 0.17 & 0.22 \\
\hline
\end{tabular}

\section{Source: UNCTAD Handbook of Statistics, uncomtrade}

Table 7 shows that the export share of total road vehicles in the world export of automobiles increased from 0.20 percent in 1995 to 1.10 percent in 2017. It indicates that demand for the automobiles in world has been increasing slowly. The market shares of all the vehicles in world have been increasing since 1995. It indicates the growing demand for Indian vehicles in world. The market shares of 'Cycles, etc Motorised or not' increased significantly to 4.39 percent in 2017. This is followed by 'Motor vehicles parts, Accessories nes'. The market shares of 'Trailer non-motor vehicles' in world was very low over the period.

Graph 6: Market Shares of Automobiles in World

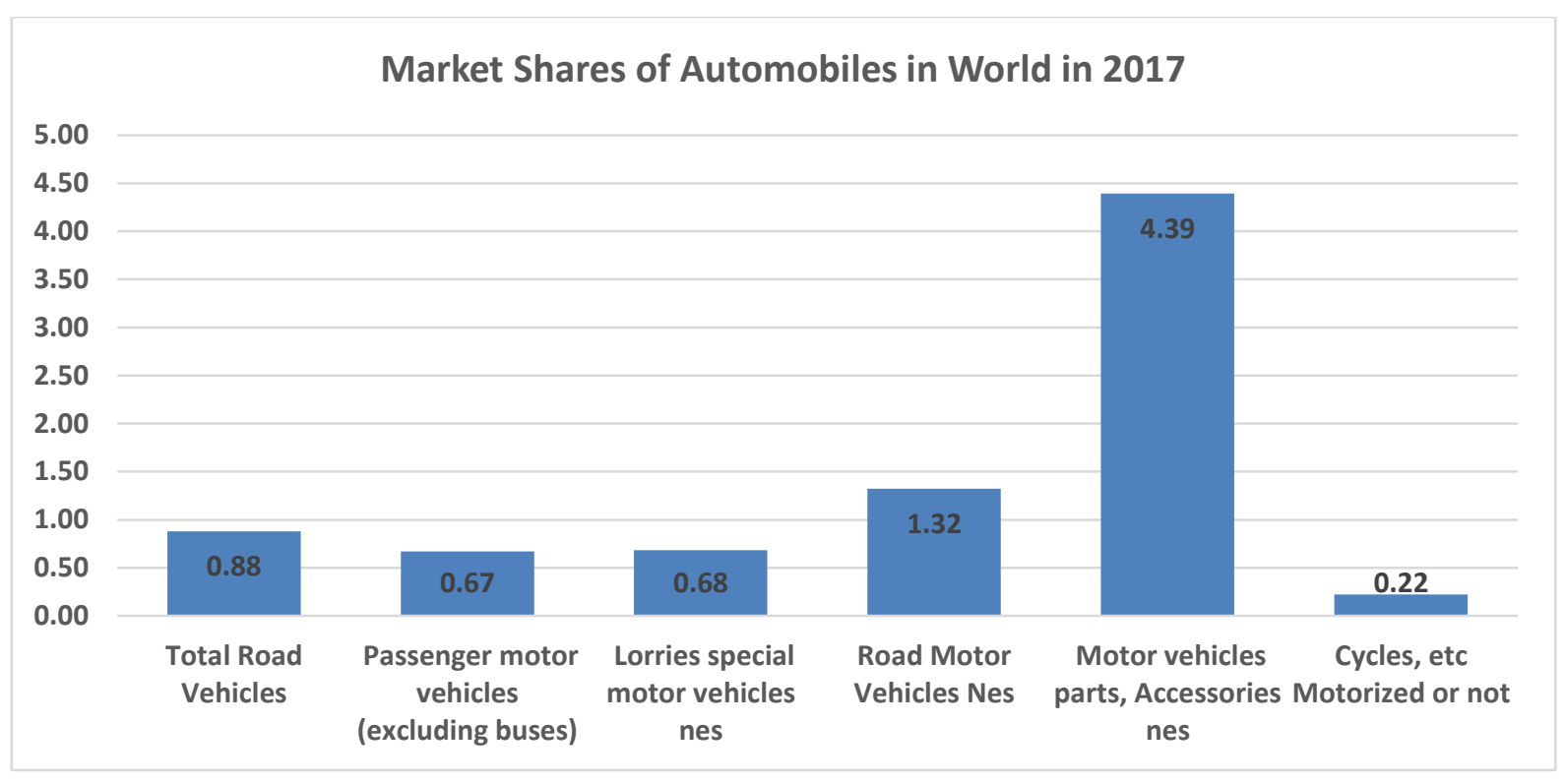

\section{Revealed Comparative Advantage (RCA) of Automobiles}

Table 8 shows that revealed comparative advantage of automobiles over the period 2001 to 2017 . A product can be said to have export potential and competitive advantage if index value is 1or more than one and value less than one indicates competitive disadvantage. 
Table 8: RCA of Automobiles

\begin{tabular}{|c|l|c|c|c|c|c|}
\hline Code & Group Description & 2001 & 2005 & 2010 & 2015 & 2017 \\
\hline $\mathbf{7 8}$ & Total Road Vehicles & 0.21 & 0.36 & 0.56 & 0.62 & 0.65 \\
\hline $\mathbf{7 8 1}$ & $\begin{array}{l}\text { Passenger motor vehicles } \\
\text { (excluding buses) }\end{array}$ & 0.04 & 0.20 & 0.55 & 0.49 & 0.53 \\
\hline $\mathbf{7 8 2}$ & Lorries special motor vehicles nes & 0.12 & 0.24 & 0.48 & 0.40 & 0.40 \\
\hline $\mathbf{7 8 3}$ & Road Motor Vehicles Nes & 0.25 & 0.65 & 0.65 & 0.38 & 0.41 \\
\hline $\mathbf{7 8 4}$ & Motor vehicles parts, Accessories & 0.37 & 0.56 & 0.47 & 0.73 & 0.79 \\
\hline $\mathbf{7 8 5}$ & nes & & & & & \\
\hline $\mathbf{7 8 6}$ & Trailers, Non-motor vehicles, nes & 0.10 & 0.09 & 0.08 & 0.11 & 0.13 \\
\hline
\end{tabular}

Source: uncomtrade

At aggregate level, India has no export potential in the total road vehicles. At disaggregate level, India has export potential and comparative advantage only in the product category 'Cycles, etc Motorised or not'. India exhibited comparative disadvantage in all the remaining product categories. This indicates that Indian automobiles are unable to compete with high technology products from other countries.

According to a study concluded jointly by ICRA and SIAM, taxes such as electricity tax, octroi, VAT and state taxes add up to $10 \%$ of the manufacturing cost, making locally-made vehicles less competitive in the global market.

\section{Conclusion and Policy Recommendations}

The paper found that the production of automobiles grew at a positive rate over the period 2011-2016. Production of commercial vehicles increased substantially and India was the 7th largest manufacturer of commercial vehicles in 2018. Domestic sale of two wheelers increased gradually, it was a major part of the total production of automobiles in the country and increased significantly during 2011-2018. However, sales of all other vehicles increased with some variations over the period.

Though, India was self-sufficient in all the 6 product categories of automobiles in 2000.But India lost competitiveness in the two product categories, 'Motor vehicles parts', and 'Trailers and other vehicles parts' in 2018. The export performance of automobiles sector has been improving, as the share in total exports has been increasing since 1990.The market shares of all the automobiles in world have been increasing since 1995. The compound annual growth rate (CAGR) of total Road vehicles as well as of all the vehicles declined significantly during 2011-2018. This was due to slow down in global economy. Revealed comparative index showed that India has no export potential in automobiles. It showed export potential only in the product category 'Cycles, etc Motorised or not'. Comparative disadvantage in automobiles was due to the low production and high duties on 
imported items and intermediately products used in the production of automobiles. High cost imported raw material increased the cost of production of automobiles and made them globally less competitive.

The following are the policy recommendations to enhance the competitiveness of automobiles sector.

Innovations are required in the automobile industry. Research and development activities in the production sector should be carried out in order to improve the quality of automobiles and to make them competitive in the world market.

Automobile sector should consider changing preferences of the consumers. Consumer demand for fuel-efficient vehicles like electronic vehicles has increased. There is a need of innovation in the automobile sector. New technology should be used to make competitive products.

Lack of infrastructure facility could be a barrier in the growth of the vehicle industry. Good infrastructure facilities should be provided in the country. This would help to increase demand for automobiles in India.

There is no shortage of labour in India, but there is a scarcity of skilled labour. Reforms are required in the labour market to make them skilled and trained. Government should organize training programme for the workers. Only trained and skilled labour should be used in industries to make internationally competitive products.

The production of automobiles depends on certain imported items and intermediary products. For example auto grade steel is not being manufactured by the local industries and India is dependent on countries like Korea and Japan. Hence import duties should be reduced on these items to reduce the cost of production.

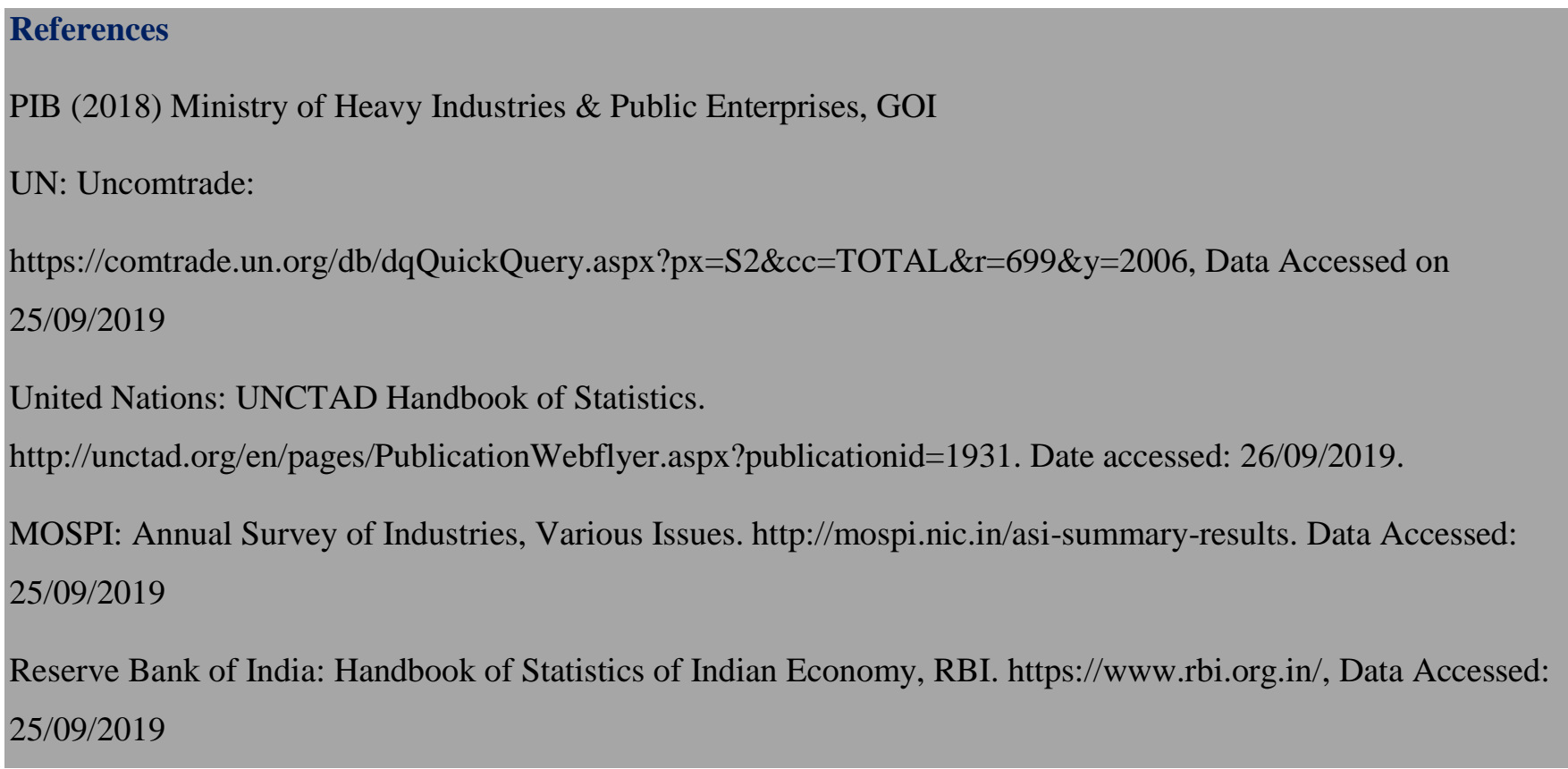

